\title{
10
}

\section{Rethinking Freshwater Management in the Context of Climate Change: Planning for Different Times, Climates, and Generations}

Climate change is overwhelmingly framed in global narratives as one of (if not the most) pressing issue facing humanity in the twenty-first century. Common depictions declare it as a fundamentally new phenomenon that threatens apocalyptic environmental changes and the survival of both human and nonhuman beings. Climate change (as one of the markers of the Anthropocene epoch) is framed as fundamentally new and unpredicted and therefore requires radical interventions, global actions, and new approaches. Warnings from the 2018 Intergovernmental Panel on Climate Change (IPCC) report Global Warming of 1.5 C identified the need for collective actions to lower the amount of greenhouse gas (GHG) emissions entering the atmosphere to avoid dangerous climate change (Hoegh-Guldberg et al. 2018; Roy et al. 2019). If societies fail to reduce GHGs within the next few decades, the global earth system could cross the climate 'tipping point' (of $2^{\circ} \mathrm{C}$ increase in the global average air temperature). The results of crossing this point would be widespread loss and damage to human and ecological communities, including the extinction of certain species, collapse or serious disruption of ecosystem functioning, ocean acidification, sea-level rise, more intense extreme weather events and increased food and water insecurity (Hoegh-Guldberg et al. 
2018). Climate change is framed as an urgent issue that requires immediate and largescale collective actions by individuals, civil society, industries, and governments to address to avoid a litany of environmental and societal disasters, which raises critical questions for freshwater governance and management in Aotearoa.

Indigenous peoples are one of the most important groups of voices in climate change debates, with their discourses referencing environmental and intergenerational justice. Their concerns are two-fold, including both the environment and the continuation of specific cultures linked to particular places and ecosystems. It is these relationships "between the processes of the natural and social worlds" (Schlosberg 2012, p. 451), which are crucial to Indigenous framings of Indigenous Environmental Justice (IEJ). Such a framing does not imply a dogmatic "living in the past" wherein Indigenous Peoples' must choose to live how their ancestors did. Instead, it emphasises how Indigenous societies are dynamic, living, and unique cultures and that a diversity of ways of life (incorporating different knowledges and values) are possible (Durie 1998). Instead, this discourse supports the creation of environments that maintain and enhance dignity (for both current and future generations) in which there are intimate and reciprocal relationships between humans and nonhumans (Alfred 2008, 2015; Watene 2016).

Notwithstanding the urgency of acting and the need to take climate change seriously, Indigenous and decolonial scholars increasingly challenge hegemonic narratives that attribute responsibility for climate change to human actions without also recognising the impacts of colonisation on Indigenous peoples. Such scholars raise critical questions about what climate change means in the context of IEJ and how efforts to address climate change can be (or already are being) interwoven with Indigenous peoples' efforts to reassert their knowledge, values, and practices in the context of freshwater governance, management, and restoration efforts. As we demonstrated earlier, settler-colonialism has violently uprooted Indigenous peoples (including Māori), communities, altered environments, and undermined human-more-than-human relations. Indeed, Indigenous peoples have (over the past two hundred plus years) faced (and continue to face) catastrophic social and environmental changes (dubbed "the end of worlds" by some Indigenous scholars) 
including radical changes to freshwater systems. This has led some scholars to point out that "colonialism is itself a form of anthropogenic climate change" (Parsons and Nalau 2016; Whyte 2020, p. 5), and to suggest Indigenous peoples are among the first survivors or victims of climate change (Whyte 2017). Whyte asserts that the heightened 'vulnerability' of Indigenous peoples to the negative impacts of climate change (rising sea levels, extreme weather events, biodiversity loss, and so on) are not the result of either "bad luck" or the confluence of two unfortunate events (colonisation and climate change), but are critical components of the structures and practices that created the Anthropocene.

For many Indigenous peoples, the drastic alterations experienced because of colonisation are (in many instances) more extreme than the apocalyptic warnings written by climate change scholars, journalists, and activists if we exceed $2.0^{\circ} \mathrm{C}$ of warming (Cameron 2012; Carter 2018; McMillen et al. 2017; Rumbach and Foley 2014; Veland et al. 2013; Vinyeta et al. 2016; Whyte et al. 2019). Indigenous scholars, including Whyte (2017) and Todd (2016), argue that achieving climate justice for and by Indigenous people requires addressing the multiple ways in which global environmental changes (including freshwater degradation and the various impacts of climate change) are also inextricably related to, and in reality, predicated on, settler-colonialism (Zahara 2017). This includes drawing attention to the ontological assumptions that underpin understandings of climate change and which shape responses at local, national and international scales. Key among these assumptions is that conceptions of time are universal across cultures and peoples, and that time is linear. For many Indigenous cultures, however, including Māori, time is non-linear and conceptualised as a spiral or temporal loop (StewartHarawira 2005, 2018); past/present/future are conceived as holding concurrent status and existing together such that no time is privileged over another. For Indigenous scholars, such as Christine Winter, Indigenous conceptions of time raise important questions about the intergenerational environmental justice (EJ) implications of climate change for Indigenous peoples.

In this chapter, we explore justice as an intergenerational imperative for Indigenous peoples by examining how different conceptions of time shape responses to climate change. We offer insights into how bringing 
Māori understandings of time can open new spaces for thinking about and planning for climate change in ways that do not reinforce and rearticulate the multiple environmental injustices (disproportionately experienced by Indigenous peoples because of settler-colonialism). The histories of Māori and other Indigenous cultures, over the last two hundred plus years of colonisation, offer important lessons about what constitutes a life well-lived and how to maintain cultures, identities, a sense of belonging and connectivity in the face of radical social, economic, political, cultural, and environmental changes. We first begin by drawing attention to growing critiques amongst Indigenous scholars to the dominant framing of climate change as an unprecedented environmental crisis for all of humanity, which overlooks Indigenous peoples' experiences of the social and ecological disaster that was (is) colonialism. We then consider developments in EJ theories that attempt to accommodate multiple generations and intergenerational rights, responsibilities, and obligations and focus particularly on the ontological framing of time as a way of overcoming the limitations of Western liberal theories founded on linearity and progress. We take these critiques through into our next section that explores climate change policies in Aotearoa, where we argue that, once again, Euro-Western knowledge and value systems are privileged over Māori ways of knowing. We contrast this by exploring Māori conceptualisations of intergenerational duties of care, specifically kaitiakitanga (environmental guardianship), and time as a way of recuperating Indigenous ways of knowing and being in space and across time to overcome environmental injustices against Māori and their environments. Next, we spiral back to the Waipā River and examine how local governments, Māori, and other actors within the Waipā catchment (and more broadly within the Waikato Region) are framing climate change, and what actions are being planned or taken in response to climate risks. In this section, we critique the dominant framing of climate change as an economic and technical problem and highlight Māori efforts to reassert their knowledge, values, and mana to address the cascade of risks (both climatic and non-climatic) facing their awa (river). We also consider the justice implications of the responses being taken (or not being taken) to address climate change for Māori and their awa by focusing on tuna (freshwater eels) as a way to highlight the ontological conflicts that 
manifest due to different conceptualisations of time, nonhumans and things that matter in the Anthropocene. Moreover, there remain critical conceptual differences when different cultures imagine what is a dignitysupporting environment for future generations (Watene 2016; Winter 2019).

\section{Indigenous Critiques of Climate Change: Indigenising Intergenerational Climate Justice}

Climate change, biodiversity loss, environmental degradation, and pollution bring attention to the longer-term future and raise questions about the temporal dimensions of environmental justice. Decisions of individuals, businesses, and governments that affect lands, waters, biodiversity, and atmosphere have both current and longer-term impacts. The formulation of these decisions within the dominant Western worldview continues to marginalise Indigenous worldviews, modes of living, and cultural norms. Candis Callison writes, in regard to the Indigenous peoples of the North American Arctic, that scholars and decision-makers need to acknowledge what "climate change portends for those who have endured a century of immense cultural, political and environmental changes" (Callison 2015, p. 42).

Settler-colonialism was (is) "an attack" on the capacities of Indigenous peoples' to adapt to variable (climatic, ecological, economic) conditions; colonisation involved deliberate and incidental actions by settlers to erase Indigenous landscapes and waterscapes and supplant and naturalise the values, economies, political structures, and human-environment relations of settler-societies. Many of the anticipated climate change-related losses, damages and shocks that non-Indigenous peoples are now increasing concern and alarm about, were experienced by Indigenous peoples as a consequence of climate change. These include: drastically altered ecosystems; loss of biota; environmental degradation; destruction of economies; decline in livelihood opportunities; forced relocation; political and ontological conflicts; and socio-cultural disintegration (Brännlund and 
Axelsson 2011; Cameron 2012; Nursey-Bray 2016; Nursey-Bray et al. 2019; Parsons and Nalau 2016; Veland et al. 2013).

International conventions and agreements, including Brundtland's Our Common Future (1987), the United Nations Framework on Climate Change Convention (UNFCCC), the Sustainable Development Goals (2016), and the Report of the Indigenous Peoples' Global Summit on Climate Change (United Nations 2009) all emphasise the need to protect and maintain the climate system, and the need to ensure environmental benefits to future generations. Each document implies that intergenerational justice should be addressed, but at the same time make clear that the most important obligations must be to the living. Such documents (excluding the Report of the Indigenous Peoples) are largely written from a Western liberal worldview, and despite the various reports and agreements, environmental degradation and worsening climate change continue.

Whyte (2020) argues it is already too late to avoid climate injustices against Indigenous peoples as they are already affected by biophysical phenomena as well as socio-economic and political processes. A key reason why it is too late, Whyte argues, is that the urgency and alarm about climate change-being problematically expressed in the media, research, education, advocacy, and political decision-making-could result in actions that contribute to further injustices; chiefly, through strategies undermining Indigenous peoples' worldviews, values, governance and management approaches, and sovereignties (Whyte 2020, pp. 2-3). His argument, based on his personal and academic experiences involving his own Indigenous people (Anishinaabe peoples of the United States and Canada) as well as other North American Indigenous nations, maintains that actions to address climate change are failing to empower Indigenous collective self-determination and advance Indigenous aspirations. Instead, climate change, under the guise of urgency and the prospect of dangerous climate change, can be mobilised to justify interventions that disrespect Indigenous rights, knowledge, and ways of life. Scholars such as Cameron (writing about Canadian Inuit and First Nations) and Veland and Howitt (researching Australian Aboriginal peoples) have drawn similar conclusions (Cameron 2012; Howitt et al. 2012; Veland et al. 2013). 
A wealth of scholarship around the world highlights how governments and industries are continuing to disrespect Indigenous values and sovereignties by establishing high carbon developments; a layering of multiple recognition, distributive and procedural social and environmental injustices. These include fossil fuel exploration and extraction operations, mining, and the development of new oil and gas pipelines constructed on and under Indigenous lands and waters without the consent of Indigenous peoples. Even when there is a legal requirement for consultation with Indigenous groups and/or obtaining consent to such developments, it is frequently bypassed by claims of national security and/or urgency, as occurred in relation to the Dakota Access Pipeline and the Standing Rock Sioux Tribe and others (Baum 2019; Gilio-Whitaker 2019; LeQuesne 2019; Whyte 2017). Also, there is continued dispossession of Indigenous peoples from their lands and waters (through new hydropower and forest conservation schemes) under the auspices of climate mitigation and lowcarbon energy transition policies (Baldwin 2009; Dressler et al. 2012; Li 2010; Yenneti et al. 2016). Similarly, scholars argue that the majority of government- and NGO-led programmes aimed at encouraging lowcarbon energy developments or the resettlements of Indigenous communities deemed highly vulnerable to climate risks in the Arctic violate the justice principles of contest, trust, accountability and reciprocity. This means Indigenous peoples experience further environmental injustices because of climate change policies and actions.

Climate change has focused Western scholars such as Derek Bell, Tim Hayward, Simon Caney, and Henry Shue on the issue of climate justice and intergenerational justice largely because climate change and its impacts are so long-lived (Bell 2011, 2013; Caney 2009, 2014; T. Hayward and Iwaki 2016; Shue 2014). For example, the lag time between when a GHG is emitted and its warming effect on the atmosphere occur is on average 50 years. Likewise, the cumulative and cascading effects of climate change on the environment are predicted to worsen in the future. Invariably, these scholars draw on Western liberal justice traditions and their arguments centre on the claim that dignity and equality, guaranteed under international agreements such as the United Nations Declaration of Human Rights, are not temporally bounded. This means it is insufficient to just guarantee and protect the rights of human 
beings living now; those same obligations and duties need to be carried forward to include future generations of people (Caney 2008). This entails ensuring the state of the environment remains at the same or similar state (with no worse degradation and similar benefits) from one generation to the next so that the environment passed on to future generations is in no worse state than what was inherited from ancestors.

Western liberal theories of climate justice (which remain dominant within the international scholarship and policymaking domains) claim neutrality, impartiality, and universality and, thus, do not consider the life-and dignity-supporting environments peoples around the globe (including those from non-Western cultures) need in the context of changing climate conditions. Western justice theorists, like politicians and economists, have struggled to conceptualise obligations of justice that include distant futures where the beneficiaries are not clearly identified, and their future circumstances cannot be truly fathomed or predicted with any certainty. In developing policies and taking action to address climate change and other environmental problems, decisions often favour the present over the future. For instance, cost-benefit analysis, which is used frequently by economists and policymakers to evaluate the effectiveness of spending and investment to address climate change, apply uncertain discount rates over a relatively short time frame (100-150 years) that can unfairly distribute benefits to people living today and disadvantage future generations (Caney, 2008; Stern et al., 2007; Winter 2018).

Simon Caney argues that future generations of people possess the same basic rights as current living people (the right to life, the right to health, and the right to subsistence) (Caney 2008, 2009). Each of these rights is threatened by climate change (both now and in the future) and impacts on environments that undermine peoples' rights to life, health and subsistence. This argument could be expanded to include the pollution of waterways, land degradation, biodiversity loss, and so forth (on a more localised level). A limitation of this rights-based justice structure is, however, that it focuses on protecting the environment only insofar as it supports the health, wellbeing, and capabilities of human beings (as individuals). Life, moreover, is a constrained definition. Human beings are conceptualised primarily as individuals and individual human rights 
are emphasised. Moreover, communities do not extend to include the interests (or people's obligations towards) ancestors (or the past more broadly), ecological communities, or the environment (and more-thanhuman actors). Although, under the United Nations Declaration on the Rights of Indigenous Peoples (UNDRIP), the declaration states that Indigenous knowledge, values, and relationships with nonhumans must be guaranteed and protected (Articles 1, 8, 12, 25). For Indigenous peoples, these protections are issues of Indigenous rights.

In contrast to intergenerational environmental justice theorists who claim a linear projection in which both the living and generations of people in the near future accumulate the majority of duties and obligations, some justice scholars emphasise obligations to ancestors in their theorising. Duncan Ivison's exploration of the normativity of Western liberal political thought raises questions about how the assumed universality in "understanding and reflecting upon social and political relations" affects Indigenous peoples' rights (and their understandings of rights) as they relate to their land, culture and self-rule (Ivison 2014, p. 1). Ivison argues (Ivison, 2003, p. 336) that accommodating Indigenous rights may require departures from Western liberal norms to conceive Indigenous rights as coexisting with those of the settler state. Edward Page suggests a way to overcome the hopelessness of establishing social contracts with undefinable future individuals is to view intergenerational justice through the lens of reciprocity: "considered as either mutual advantage or fair play" (Page 2007a, p. 226). This theorisation acknowledges the benefits inherited from one's ancestors and the attendant obligations for future generations and positions intergenerational justice as a form of intergenerational custodianship or environmental stewardship.

Page criticises the neglect of ancestors and argues the need to consider ancestors in accounts of the impacts and implications of environmental degradation and change and in determining how the benefits and costs associated with environmental changes are distributed. As custodians, there are constraints on how one generation may use the environment: "existing persons are bound by duties of indirect reciprocity to protect environmental and human resources for posterity in return for the benefits inherited from their ancestors" (Page 2007b, p. 233). He emphasises how people's lives are built on the work of past generations and depend 
on a stable climate system conducive to human dignity and flourishing, clear waterways and air, stable and productive solids, and abundance of forest, fisheries, and agricultural products needed to sustain humans on earth. However, Page's conceptualisation of time to generations past, present, and future remains distinctly (like other scholars, including Parfit) anthropocentric (Page 2007a; Parfit 2011). Page overlooks the intrinsic need to preserve and protect the nonhuman (Schlosberg 2012; Winter 2018). In his conceptualisation of intergenerational environmental justice, the protection and responsibilities attached to environmental custodianship are for the benefits of future generations of people. Although the result may be the protection and care of nonhumans, the primary focus is still human needs and desires. He does not express any normative obligation to nonhuman actors. In marked contrast, within Indigenous philosophies (including the concept of kaitiakitanga from Māori people of Aotearoa and the concept of kanyini from the Anangu people from central Australia) there are normative responsibilities and duties of people towards nonhumans, and these duties are built upon a non-Western conceptualisation of time (Winter 2019).

Scholars, such as Winter (2018), offer conceptualisations of intergenerational environmental justice that take into account Indigenous ontologies and which expand on theorisations of justice focused on individuals located in the present and which disrupt Western assumptions about time; specifically, the ontological presumption that time always moves forward and that individuals exist only in one discrete time. Linear temporality is, according to Tilley, perhaps the most "taken-for-granted Western social discourse" (Love and Tilley, 2013). In Western imaginaries, time is a progressive forward seeking arrow. Time is a commodity or material to be lost, to be utilised wisely (but not to be squandered), and to be measured by minutes and seconds, by light years, and the moon and sun (Winter, 2019). Time (conceptualised as a time as a spiral) is something that stands still, persists, speeds by, and repeats itself. It is something dark, fleeting, and illuminating.

Winter (2018) refers to her own whakapapa to demonstrate the relatedness and interconnectedness of time and all other things, human and nonhuman, and the multiple temporalities embodied within Māori. 
I have ancestors; I live now, and I have children who will (all being equal continue live when I am gone; I will have grandchildren (all things equal, etc. While I am living, I am also a (potential) ancestor, and my living children were once a future generation to me, as are my potential grandchildren, as was I to my ancestors. In time I will be an ancestor as will my children and my grandchildren will be living and thinking of future generations. The generations are coexisting, the past is always in the present, and the future is always in the past.

Kia whakatomuri te haere whakamua (I walk backwards into the future with my eyes fixed on my past) is a whakataukī (proverb) that speaks to Māori conceptualisations of time, where past, present and future as perceived as interwoven in a temporal loop, and life is an ongoing cosmic process underpinned by whakapapa (genealogical connections). Within this neverending spiralling movement, there are no temporal restrictions (it is both past, present, and future) (Rameka 2016; Winter 2019). For Māori society, like some other Indigenous cultures, time is not framed in a way that privileges the present (over the past and future), and time does not proceed on a linear forwards pathway from past to present then future. In this way, Māori understand the past as a constant reference point. A person's actions in the present day are linked to both past and future generations of people, with the future/present/past linked together in the ongoing spiral. Likewise, Australian Aboriginal and First Nations' peoples' imaginings of time are cyclic (Davis and Todd 2017; Mckay and Walmsley 1969; Stewart-Harawira 2005; Whyte et al. 2019; Winter 2019), and emphasise how the past and future are close companions to the present day (Povinelli 2016; Povinelli et al. 2017). What these diverse Indigenous philosophies hold in common is that the "past and future are intimate bedfellows to present" (Winter 2018, p. 34). How one behaves in the present-day thus is always referenced from the point of view of past and future generations (who are referees of what is happening now).

In contrast, Western perspectives of time tend to view the past as something behind oneself and that people's goals, aspirations and plans should be directed at the future (Patterson 1998; Winter 2018). The fundamentally different way in which Indigenous and Western cultures understand time is also reflected in the different ways in these cultures 
live with or experience the loss of the past (Stewart-Harawira, 2005; Watson, 2015). Accordingly, Indigenous people living now include obligations to past, present, and future generations in their considerations. Embedded within Indigenous environmental justice, therefore, is always an intergenerational element that embraces communal continuum, inclusive and interconnected communities, and the places responsibilities on the living to connect future generations into their ethical communities.

\section{Framing Climate Change in Aotearoa as an Economic and Technical Problem}

Freshwater systems in Aotearoa are under pressure from a diversity of factors, which will likely intensify because of climate change (Ballantine and Davies-Colley 2014; Chapman 1996; Dudley et al. 2020). Small alterations in weather conditions are likely to produce significant effects in places with temperate climates such as Aotearoa, including biodiversity loss and heighten threats to people's livelihoods (Manning et al. 2015). In the Waikato region, climate change is meant to produce a small number of positive impacts such as warmer temperatures (1-3.5 degrees warming by 2090) enabling farmers to grow new crops and pasture as well as extending growing seasons (Pearce 2019). However, a large number of negative impacts are also predicted for the region (New Zealand et al. 2020; Reisinger et al. 2014; West 2007). Warmer air and water temperatures are likely to increase the frequency and spread of invasive species and water- and vector-borne diseases, which will place additional stress on native biota as well as (non-native) livestock (Pearce 2019; Reisinger et al. 2014). The number of hot days is forecast to increase and heatwaves are likely to result in a greater incidence of heat stress amongst people and fauna. The seasonal distribution of rainfall is expected to alter as a consequence of climate change (wetter in winter and autumn and drier in summer and spring) (New Zealand et al. 2020). Heavy rainfall events, whereby large amounts of rain falling in a short amount of time, are more likely to occur in the region under changing climate conditions, resulting 
in saturated soils and flooding, slips and sedimentation of waterways. Similarly, droughts are predicted to increase (especially during spring and summer), causing reduced river flows, greater pressure of water supplies, and stress of biota (Pearce 2019; Reisinger et al. 2014).

At the national scale, efforts to address climate change focus on both mitigation and adaptation using a mix of regulatory and market-based tools. The New Zealand Emissions Trading Scheme (ETS) was created in 2007 to record GHG emissions and facilitate a new 'carbon trading' market as a way to encourage businesses to reduce their GHG emissions. The carbon-trading scheme ensured the country complied with its international obligations under the Kyoto Protocol; however, the ETS has been consistently criticised, including by Māori commentators, for failing to reduce GHGs (Harawira, 2007). For instance, Māori parliamentarian Hone Harawira (from Northland iwi Ngāpuhi and a member of the Māori Party) spoke forcefully in parliamentary debates opposing the creation of the ETS in 2007. He referenced emails he received from concerned Māori individuals around the country as well as emails from the Indigenous Environmental Network (an international NGO) in his speeches. He asked:

[I]s this emissions trading scheme really the answer to all our climate change problems, or is it just creating another property rights regime to let the world's biggest polluters continue along their merry, filthy way? Charging people for greenhouse gas emissions was supposed to encourage businesses to come up with alternatives to fossil fuels, but all it is doing is giving them an excuse to continue. Why bother with the expensive, longterm structural changes if we can meet our targets by simply buying pollution rights from operations that can reduce their carbon cheaply?

He warned the inclusion of Māori owned forests (mostly, exotic pine plantations) in the ETS would "not make any difference [to reducing GHG emissions] because all that it would do is let industrialised nations and companies [around the world] buy their way out of emissions reductions", and any financial benefits Māori received would not compensate to the damage done to the environment (Harawira 2007). Harawira sought to draw his fellow parliamentarians attention to Māori principles 
("our kaupapa [principles and ideas] of rangatiratanga [authority], manakitanga [hospitality, respect and showing care for others generosity], and whanaungatanga [the centrality of kinship]") and Māori obligations to care for and preserve the environment as encapsulated in kaitiakitanga.

[It is] our responsibility to care for our world through the reduction of those activities that would harm and, indeed, destroy that world. In the interests of life itself, let alone social, economic, and environmental sustainability, we have a responsibility to reduce our carbon output. Māori have a role to play in the reduction of greenhouse emissions, and we do not resile [sic] from that responsibility, but Māori also have the right to manage what little assets they may have for the betterment of their people. We realise that in order to manage both roles effectively we must-and we do-appreciate that our total wellbeing, our health, our economy, and our sustenance are dependent on the wellbeing and health of our world, just as all indigenous peoples across the globe understand their unique role of caring for and conserving mother Earth.

While Harawira's comments, as an individual and a member of a particular iwi (Ngāpuhi), cannot be taken to mean that all Māori in Aotearoa felt the same way about the ETS; however, it does indicate that Māori were seeking to (once again) get their knowledge, values, and intergenerational generational responsibilities recognised by the settler-nation but were still being disregarded (misrecognition) by those holding power.

The nation's total GHG emissions continued to rise, chiefly from methane generated from cows (with the agricultural industry not part of the ETS) (National Business Review 2018; Unknown Author 2009). Since its creation, the ETS has been subject to review and reform to improve how it functions and to ensure it works as a mitigation strategy. With regard to adaptation, the Climate Change Response (Zero Carbon) Amendment Act 2019 situates adaptation planning and action as primarily the responsibilities of local governments; however, the Minister of Climate Change is required to prepare a national adaptation plan to guide local governments.

Both the ETS and the Climate Change Response (Zero Carbon) Amendment Act 2019 reflect Western ontological and epistemological 
views that seek to command-and-control nature (with nature kept apart from culture) through technical knowledge (scientific and economic) and maximise economic productivity. For instance, the ETS (and other carbon trading schemes) rearticulates many of the same ideas and approaches used by past generations of settlers (as individuals and governments) to address environmental problems (rendered a scientific, technical, managerial problem) (Baldwin 2009; Driver et al. 2018; Gerrard 2012). However, there remain critical issues with the ETS as a supposed solution to rising GHG emissions, particularly since the same capitalist market forces that drove the industrial revolution, colonialism and imperialism, and high carbon economies and lifestyles, are now meant to be able to solve the problem of climate change. Recent research by Māori scholar Lyn Carter (from iwi Ngāi Tahu also spelt Kāi Tahu) argues that the ETS, from its initial creation through to its implementation, persistently excluded mātauranga Māori (Māori knowledge) and values (Carter 2018). There was (and continues to remain) a persistent tension between the ETS (as an economic-focused climate mitigation approach built on exploitative capitalist models of the endless accumulation of goods) and the principles and practices of mātauranga Māori and tikanga, which centre on notions of kaitiakitanga (guardianship) and whakapapa, and intergenerational justice.

The Zero Carbon Act is framed solely from a Euro-Western (or more specifically, Te Ao Pākehā) perspective of time and decision-making time frames, which overlooks Māori understandings of time and intergenerational justice. In addition, the requirement on governments to recognise and take into account Māori values provides weaker statutory requirements than the Resource Management Act (RMA), 1991 (which we critiqued in Chap. 5). There is an absence of recognition-based environmental (climate) justice considerations and lack of a clear pathway for achieving procedural-based justice (with no specific mechanisms detailed to allow Māori to meaningfully participate-as Treaty partners - in national adaptation planning). Thus, the legislation leaves room for interpretation that could compound environmental injustices for future generations through inequitable planning regimes (which reinforce settler-colonial supremacy, western scientific knowledge, and Pākehā values at the exclusion of Māori and other ways of knowing and being). 
The framing of climate change through a Te Ao Pākehā economic lens aligns with ongoing neoliberalism and a techno-managerialist approach in which climate change is a problem to be expertly remedied, avoided or mitigated through market-led mechanisms (most notably the ETS) and new low-carbon economic development schemes. The economic threat posed by climate change is especially strong due in part to the large portion of GHG emissions produced through agriculture (methane from cows) and the dairy industry's ranking as the country's top international export earner (Adler et al. 2013; Driver et al. 2018; Hopkins et al. 2015). Within the current paradigm, climate change is largely rendered an object to be measured (through scientific knowledge) and managed by selected actors (which includes governments, iwi organisations, businesses, share market brokers and other experts), but not something that requires radically different knowledge, values, or practices to be adopted. This means that Māori experiences of disastrous environmental changes, their knowledge of how to live with and adapt to uncertain and changeable environmental conditions, and their visions of what constitutes living well remains largely marginalised within the dominant narratives of climate change.

In the context of the Waipā River, the framing of climate change as an economic problem has been internalised at the local level (including the Waikato Regional Authority, hereafter, WRA) and is evident in institutional responses to climate change. For instance, in December 2019 the WRA held its first workshop on climate change to "dig into what they could see [happen in the Waikato catchment] over the next 20 to 60 years" (Unknown Author 2019). In an official statement, Chief Executive of the WRA Bob Penter stated (in a local newspaper):

It's hard to imagine that climate change isn't going to be a factor if we've got 70 years still to run on achieving the vision of a restored Waikato and Waipā river catchment. ... For us [at the WRA] it raises questions around climate change resilience, adaptation and starting to at least consider what we might need to think about when making funding decisions for [river governance and management] projects in the future to ensure they will endure if climate change is going to be a factor in their success. (Unknown Author 2019) 
While the workshop included presentations on climate change impacts, resilience and the need for adaptation (Linwood 2019; Pearce 2019), overwhelming focus was on the economic dimension of climate change (Brownsey 2019; Dickie 2019; Ledgard 2019; Waikato River Authority 2019). Indeed, the narrative of climate change as an economic problem (as opposed to social, political, ecological) for institutions, businesses, farmers, iwi, and individuals, including those involved in freshwater governance and management, translates into an emphasis on economic and technical solutions designed to maintain, protect and intensify economic productivity (Brownsey 2019; Dickie 2019; Ledgard 2019; Linwood 2019). Thus, responses to climate change were limited to identifying financial opportunities (co-benefits) to those landowners and businesses in the Waikato willing to invest rather than being recording and addressing the social, economic, cultural, and ecological risks.

Iwi representatives noted that (within Waikato and Rohe Pōtae) local governments (regional councils and district councils) continued to pay limited attention to climate change aside from the potential for economic development (for example, through increased flood risk) as well as limited discussion of technical interventions designed to address individual climate risks. Where mitigation strategies were promoted, these remained underpinned by a language of ongoing economic growth and technological advances, which echo the earlier decades' narratives of settler-colonial land and river 'improvements', development and settlement, and everincreasing productivity. In many instances, international scholarship demonstrates, such technical and economic 'fixes' provide new footholds for neoliberal capitalism (which remained deeply intertwined with settlercolonial projects) (Nightingale et al. 2019; Pelling et al. 2012).

Flooding of the Waipā River remains an ongoing concern for the Waikato Regional Council (WRC) and the district councils in regards to climate change (which came a feature of the waterscape after drainage works and deforestation as shown in Fig. 10.1 and Fig. 10.2). Previous government-led interventions focused on draining the wetlands, straightening waterways, dredging riverbeds, removing vegetation, supplanting Indigenous biota with exotic, and controlling flooding through levees; all of which took place in the context of Māori dispossession and marginalisation. Such interventions were narrated as vital necessities to ensure 


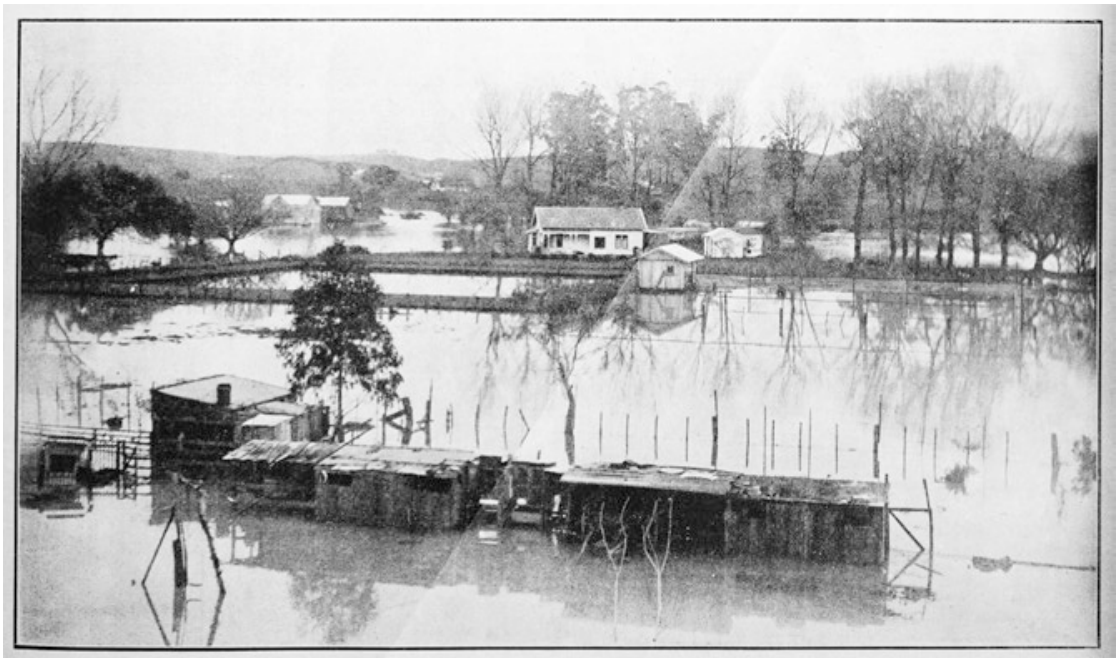

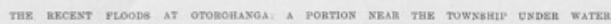

2. A. Thrm nheses

Fig. 10.1 Photograph of flooding in Otorohanga. Published in the Auckland Weekly News 17 June 1920. Photograph taken by J. A. Parry. Source: Auckland Libraries Heritage Collections AWNS-19200617-31-4

economic security and societal (more specifically Pākehā) progress. Yet, radically remaking Aotearoa's freshwater systems (as we demonstrate in Chaps. 3 and 4) through the removal of wetlands resulted in more frequent and greater intensity flood events within the Waipā catchment (see Fig. 10.2, Fig. 10.3 and Fig. 10.4).

In the context of the Waipa River, iwi representatives recall the long history of local government-led engineering works along their awa and the ways in which flood levees (stopbanks) caused negative effects on tangata whenua (people of the land) and on aquatic biota. One iwi member recalled her family being made homeless because the local government acquired their land to build the Otorohanga flood control scheme (which was established following the 1958 flooding see Fig. 10.5) (discussed in Chap. 4). Others spoke of how engineered "solutions" to flood controls destroyed flora that were harvested by tangata whenua for food, medicine, and cultural practices. The loss of vegetation also meant there was little habitat for aquatic fauna and no places for metaphysical beings (such as 


\section{Flooding Waipā River catchment 1867-1907}

As reported in local newspapers and government reports

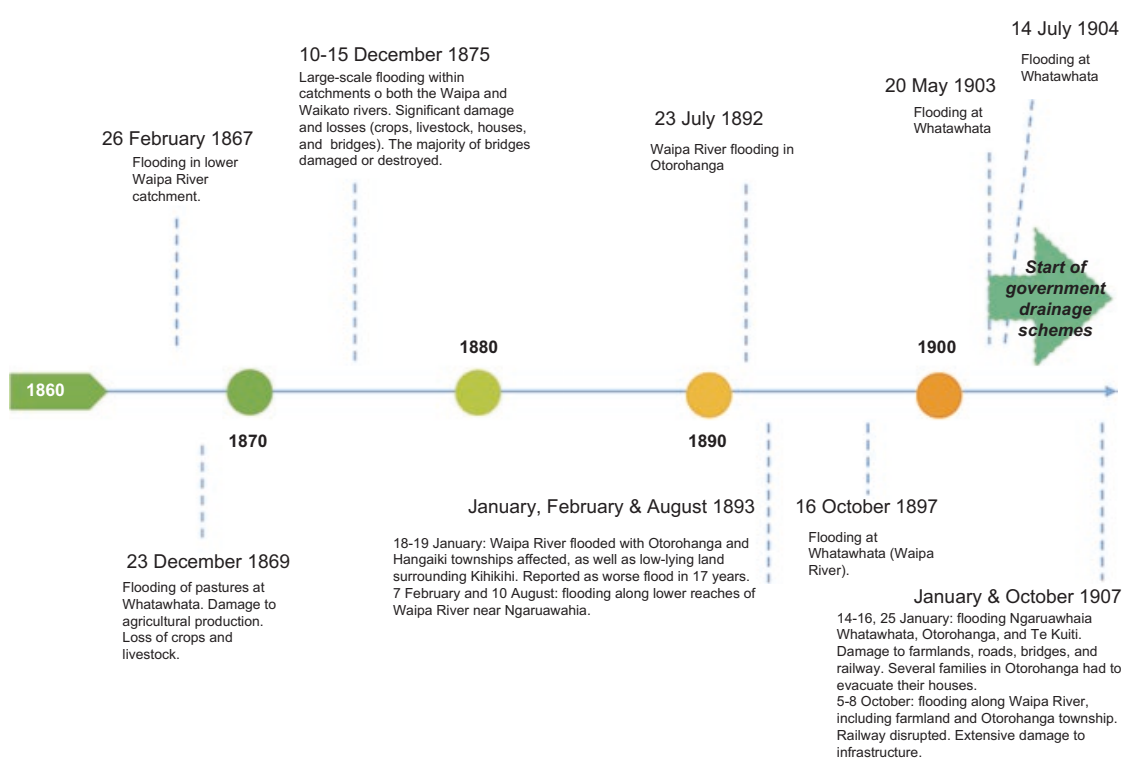

Fig. 10.2 Timeline of flooding 1880-1910. Source: Created by Meg Parsons

the taniwha Waiwaia) to rest. Thus, Māori lost more than kai (food) from the imposition of hard adaptations designed to keep water away from people and properties (Iwi Rep 4 2020; Iwi Rep 6 2020). As discussed previously in Chap. 4, Ngāti Maniapoto interviewees spoke of how floods were not perceived as "bad things, [it] would help [with tuna and other fish] migration" (Iwi Rep 6 2020), and emphasised the disaster of colonisation. Hapū-led restoration projects along the Waipā River and its tributaries are deliberately considering how they can address flooding without using hard adaptations and seeking to use their knowledge to facilitate more just outcomes (for themselves, their awa, and their more-thanhuman kin). As one iwi representative recalled: "we thought of the [incidence] of the ... 100-year flood, if we [didn't] put a stopbank [a flood levee] around our marae [tribal meeting complex], how could we slow her [the river] down" and start "planting along the river" (Iwi Rep 4 2020). 


\section{Flooding Waipā River catchment 1910-1960}

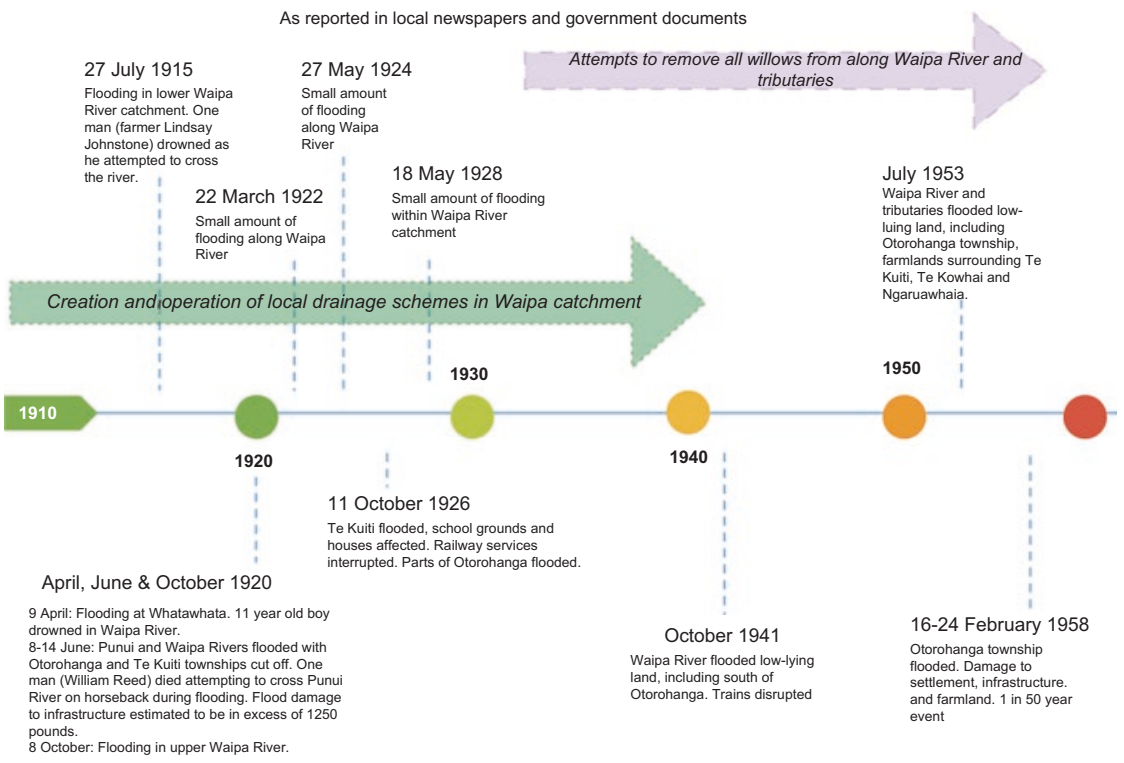

Fig. 10.3 Timeline of flooding 1910-1960. Source: Created by Meg Parsons

The continued use of engineered flood control structures within the Waipā River catchment illustrates clear evidence of path dependency within flood risk management institutions (see Fig. 10.5: Flood control scheme in Otorohanga established after the 1958 flood); it also demonstrates the persistent lack of recognition and procedural inclusion of Māori values, knowledge, and practices (all of which was supposedly guaranteed under various legislation). For more than a century, Māori along the Waipā River have expressed their concerns about the negative impacts of such physical structures on flora and fauna, their capacities to access mahinga kai (food gathering sites), and wahi tapū (sacred sites) sites (as we discussed previously in Chaps. 3 and 4) but they still lack equitable and fair outcomes.

Non-Māori local government officials and staff from NGOs in the Waipā catchment we interviewed situated "flooding issues" as complex matters of science and technology, rather than of importance to Māori. 


\section{Flooding Waipā River catchment 1958-2010}

As reported in local newspapers and official government reports

9 September 1960

flooding at Ngaruawahia, Otorohanga,

and Te Kuiti of farmlands and roads.

Waipa River and Mangaokewa Stream flooded

\section{July 1961}

Flooding on Waipa River. One

man drowned attempting to

cross river in boat.

June-July 1968

moderate flooding of farmland
July 1998

Te Kuiti, Otorohanga, and lower Waipa catchment. Waipa River burst its banks at Te Kuiti flooding thre Waipa River burst its banks at Te Kuilt flooding thr houses. Pastures and roads a fected. Waipa River period 48 years (at Otorohanga).
July 2002

flooding of "productive

farmlands" along Waipa

River. Estimated return

period 20-50 years (at

Otorohanga).

February 2004 Minor flooding
Waipa River

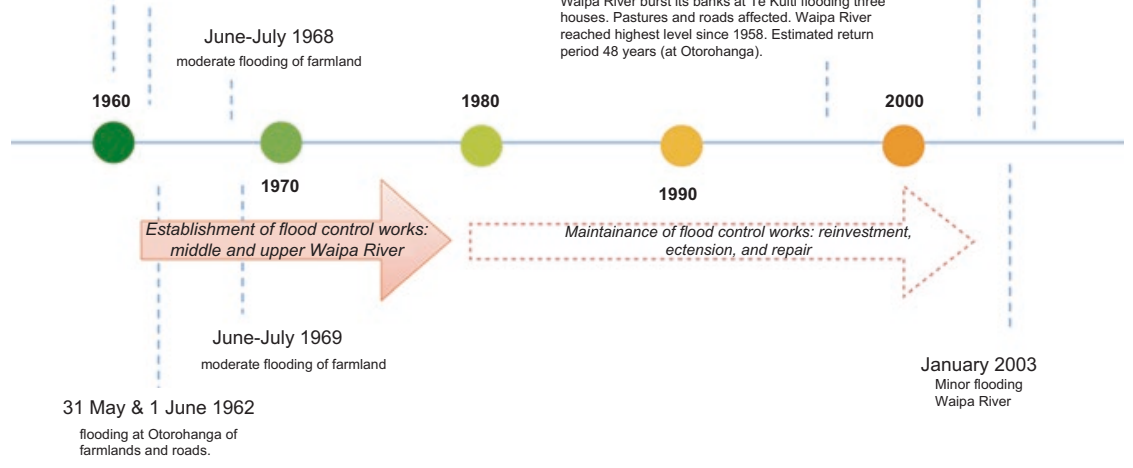

Fig. 10.4 Timeline of flooding 1960-2004. Source: Created by Meg Parsons
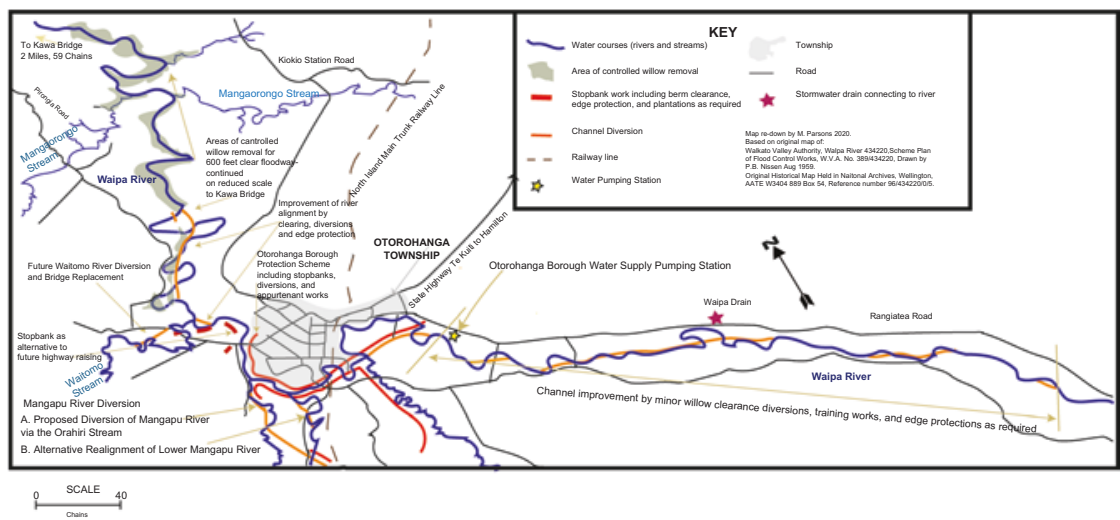

Fig. 10.5 Otorohanga flood control scheme established in 1959 following a major flood event affect Otorohanga township in 1958. Source: Created by Meg Parsons 
No mention was made of mātauranga Māori for flood control. Flooding was, one Environmental NGO employer declared, a "technically difficult" problem and was "reasonably risky work in terms of failure"; the reference to failure alludes to the potential for flood defences, such as levees, to be breached during flooding and cause damage to property, infrastructure, and lives/livelihoods. The possibility of failure, the NGO worker maintained, was:

particularly [notable in the context of] climate change and the weather we've been having [in the Waikato with] the frequency of flood events enabling those things [already] establish[ed] before ... [to] get washed out [was a ] bit of an issue. (NGO Rep 1 2017)

One NGO employee depicted flooding as a scientific and technical issue to be solved by engineering solutions. Such a view is widespread in Aotearoa, with flooding narrated as a problem that can be solved by better science (including improved flood modelling and flood monitoring systems) and more extensive flood levees (Parsons et al. 2019). Yet, a wealth of scholarship criticises such a narrow perspective of how to manage flood risk, particularly in the context of climate change. Indeed, fluvial geomorphologists and freshwater ecologists now acknowledge that not only do such hard adaptations cause negative impacts on biodiversity, but such structures also fail to protect human communities from largescale flood events in the long-term. This is demonstrated by recent flooding events around the globe (the Rangitāiki River in Aotearoa, the Brisbane River in Australia, and the Mississippi River in New Orleans, to name just a few) (Cook 2016, 2018; Myers et al. 2008; Parsons et al. 2019; Rohland 2018; Schlosberg and Collins 2014).

Iwi representatives indicated an awareness of climate change as a threat to their wellbeing and the Waipā (both materially and metaphysically), though acknowledged they did not comprehend the severity of possible climate change impacts on their awa fully. Two iwi representatives, who were involved in hapū-led environmental management and river restoration projects, noted that district councils were "not to our knowledge" considering the risks of climate change in their planning and strategies (Iwi Rep 4 2020; Iwi Rep 6 2020). 
[F]or me anyway- [the councils' focus is] about getting more industry in the area to enable the councils to do more. They're [the council] more focused on ... the day to day running [of council services] and how the long term [development] plans and those sorts of things, as opposed to restoring the awa. (Iwi Rep 6 2020)

Iwi representatives were concerned about the focus by local governments on metrics of poor river health (poor water quality) but not on other issues affecting their awa beyond its chemical and physical properties. Ngāti Maniapoto interviewees expressed concerns over water scarcity due to the lack of consideration by WRC of over-allocation and over-extraction, and the risks climate change poses to the health and wellbeing of human and more-than-human actors within the Waipā catchment. Iwi representatives were particularly concerned that WRC continued to grant resource consents to allow extraction (by residential, commercial, and agricultural users), despite claims that water was already over-allocated. One iwi representative argued that the WRC (and district councils) could learn from experiences in Australia with water overallocation, insecurity, and degradation as a "guide" of what not to do in the Waipā catchment. Specifically, one iwi representative warned that continued extraction could lead to the river system becoming like the systems of South-Eastern Australia (most notably the Murray-Darling Basin) where states allocated water to residential, commercial, and agricultural operations with almost no consideration of water supplies and climate conditions. This led to reduced instream flows and a situation in which rivers could no longer sustain human or ecological communities, with huge costs and damages not just in monetary terms, but also in terms of Aboriginal communities' capacities to access and use resources, maintain their relationships with their tribal lands and waters (their country), and protect their physical and spiritual health and wellbeing. Thus, decision-makers could learn from mātauranga Māori and recent histories of river mismanagement in Aotearoa, as well as other global histories and other knowledges as a way to adapt to the impacts of climate change: 
I think water again in the future is going to be a huge issue if we don't sort it out now, because climate change is upon us and really, we're only guessing what's going to happen in the future... [and] the water's getting less and less every year. (Iwi Rep 5 2019)

According to one iwi representative, local governments were shortsightedly exploring economic and technical solutions, including transporting water from one catchment to another (from the Waikato to the Waipā) to offset growing water demand in the Waipā catchment. The iwi representative spoke of writing to the Waipā District Council to complain about proposals to allocate and transfer water outside of the catchment and to draw attention to the interrelatedness of the Waipā River and the land:

why can't you just go through a catchment response, talk to [people up in the headwaters near Waitomo] about using up some of the [water] allocation from up [the Waipā] river ... rather than bringing it across from Waikato into the Waipa? I said it doesn't make any sense to me. ... It's a bit like a person who needs a blood transfusion because they've been going out partying all their life and I go to you oh, can you give me a blood transfusion? You say yeah, but you carry on your lifestyle, eh? You don't change. Well in time you're going to become unwell giving me all your blood.

The reference to blood reflects Māori understandings of the river that they whakapapa (genealogically connect) to as their lifeblood (Fox et al. 2017; Salmond 2020); in this case, the Waipā River and its tributaries. The consequence of transferring water from one catchment to another place is that it reduces the mauri (life force) of the water in both places and increases the risk of sickness for those who consume it. River restoration, rather than being treated as a specific practice aimed at improving water quality, is narrated by iwi as being interrelated with adjusting the ways in which people engage with and care for (enact kaitiakitanga) the whenua and the awa. It does not just focus on a single dimension of rivers, lands, peoples, or ecosystems (as everything-from a Māori worldview - is interwoven together and bound by ongoing relationships) nor does it focus on short-term decisions. Instead, kaitiakitanga allows for the possibilities of engendering adaptation through local actions. 
Climate adaptation actions around the world, including in Aotearoa, remain primarily focused on maintaining existing infrastructure or constructing new physical structures to reduce climate risks. These actions are located within Western ontologies and epistemologies (B. Hayward 2008; Parsons et al. 2019; Reisinger et al. 2011; Nightingale et al. 2019; Barnett et al. 2015; Klein 2011; Manning et al. 2015; Klein et al. 2001; Rangel-Buitrago et al. 2017). However, hard adaptations can be path dependent (simply repeating past decisions and approaches without consideration to new circumstances or past failures) and maladaptive (Barnett et al. 2015; Barnett and O’Neill 2010; Magnan et al. 2016).

Ngāti Maniapoto iwi representatives argue that, in order to address the cascade of environmental crises facing not only Te Waipā Awa (but the world as a whole), attention needs to be directed at holistic understandings of places, peoples, and human and more-than-human relations across generations. Such environmental justice is, thus, not just recognition-, procedural-, and distributive-based but also intergenerational. Only by doing this can people address the root causes of the Anthropocene as well as adapt to the impacts of climate change. Iwi representatives argue, within the context of the Waipā River, attention needs to be given to mātauranga Māori and tikanga in the context of iwi- and hapū-led decision-making processes and practices about how institutions and individuals manage (or rather maintain relationships with) the land (whenua), rivers (awa), and more-than-human actors.

\section{Kaitiakitanga and Climate Justice for the Waipā River}

In considering Māori understandings of intergenerational justice and environmental justice, it is critical to recognise justice as place-based, holistic, community-centred, and temporally spiralling. If (neo)colonial ontologies and epistemologies of ignorance (Mills 2015) are premised with existing conceptualisations of intergenerational justice, justice is incorrect, and injustices to Indigenous Peoples distributional. Worse still, as philosophers Dotson and Winter argue, if a theory of justice enacts 
"epistemological violence against and epistemological exclusion of any group of people, it is unjust" (Dotson 2011, 2014; Winter 2018, p. 36).

Within Māori ontological and cosmological paradigms, it is impossible to conceive the present and future as separate and distinct from the past, for the past is constitutive of the present and, as such, is inherently reconstituted within the future (Stewart-Harawira 2005, p. 42). Winter (2019) raises important questions about the intergenerational environmental justice implications of climate change on Māori duties as kaitiaki (guardians) and the ways in which different perspectives of time are critical considerations. For instance, questions about what time and climate change mean in the contexts of rivers as more-than-human entities (such as the Waipā), and how to formulate plans that address their best interests require careful consideration. A river is more than tens of thousands of years old, a tuna that swims in its waters can be up to one hundred years old (Anguilla dieffenbachii or Anguilla australis), each exists individually and collectively in multiple realms (material and metaphysical, morethan-human beings and ancestors) that do accord ways of seeing the world.

Within Te Ao Māori (the world of Māori), the principle of kaitiakitanga (environmental guardianship) is founded on the notion that the descendants of Papa-tū-ā-nuku (Earth Mother) need to take care of their environment. Kaitiakitanga emphasises the connections and relationships, and in so doing does not distinguish the "when" of existence thereby, creating a web of intergenerational communitarian obligations founded on the understanding that all life is entangled (human with human, human with nonhuman, nonhuman with nonhuman). It is inconceivable within this way of knowing to locate an individual outside of this entanglement. Indeed, the entanglement provides the power of the whole that must be sustained and encompasses all generations (past, present, future). In essence, the contemporaneous of kaitiakitanga binds generations together so that the mauri, mana, and wairua of all generations of iwi/hapū/whānau (living and not) are given equal consideration within decision-making; thus, when selecting what actions should be taken now (or in the near future) to address climate change, the needs and interests of current generations are not meant to be given priority over those of future generations. One of our Ngāti Maniapoto interview 
participants described how they understand the temporal and whakapapa entanglements encapsulated in kaitiakitanga and which binds generations:

kaitiakitanga is an obligation from me as her uri-Papa-tū-ā-nuku's descendant to pay attention to her hā [breath of life] to look after her. To care for her... So kaitiaki—tiaki means to look after, right—kai being I'm responsible for this-kaitiaki has a whakapapa obligation to the relationship with Ranginui [Sky Father] and Papa-tū-ā-nuku ... That's where that kaitiaki comes from. [It's] our whakapapa. Our genealogical relationship to her, to him, to all of ... the cosmos of creation [tracing] right down to us and our kai. (Iwi Rep 92019 , p. 9)

At present, the majority of decisions about how to address freshwater degradation and climate change are still largely made using Eurocentric framings and tools of assessment that do not take into account Māori conceptualisations of "concurrent past-present-future time" and intergenerational responsibilities of care (embedded in the principle of kaitiakitanga). While Māori, such as Ngāti Maniapoto, continue to practice over their rivers and lands, the privileging of state apparatuses and institutions to determine responses to climate change continue to dominate.

\section{Tuna and Climate Change}

At present, there is limited research into the impacts of climate change on Aotearoa's two species of freshwater eels (Anguilla dieffenbachia and Anguilla australis) (see Fig. 10.6); however, international research indicates that temperate eels around the world are especially vulnerable to changes associated with climate change (Aarestrup et al. 2010; Arai 2014; Drouineau et al. 2018; Jellyman et al. 2009). Freshwater eels' distinct life cycles, which include oceanic spawning grounds and the growth stage in freshwater systems, are impacted by five elements of global environmental change: 1) climate change affects the survival and drift of eel larval; 2) increased pollution contributes to the accumulation of high levels of contamination; 3) greater habitat loss and fragmentation that decrease the 


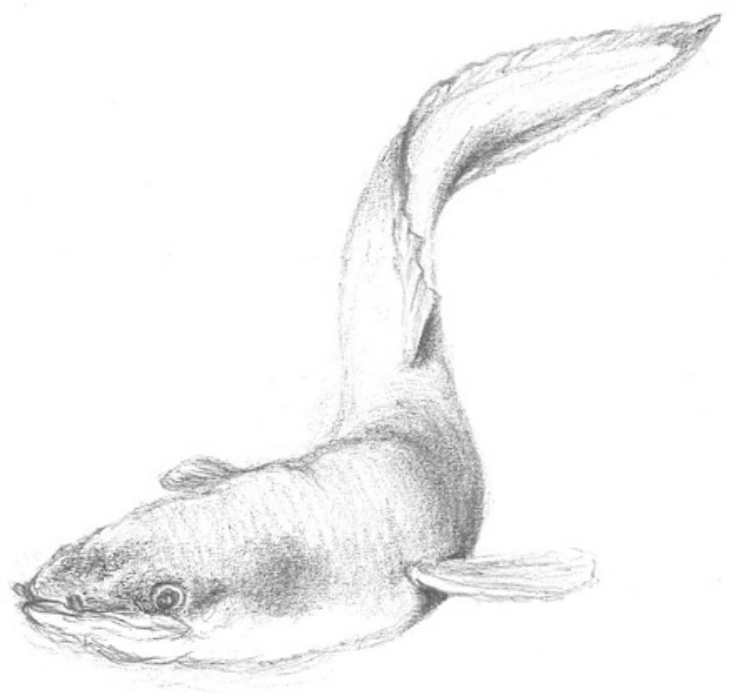

Fig. 10.6 Sketch of a freshwater eel-'Longfin eel (Anguilla dieffenbachia)'. Source Alicia Wong (artist)

amount of available habitat radically and induce higher eel mortality; 4) warmer temperatures linked to the appearance of parasitic nematode (roundworms) that reduces the success of eel spawning; and 5) the effect of recreational and commercial fisheries on eel populations (Drouineau et al. 2018, p. 903). In this context, ongoing social and environmental processes of change are likely to surpass the capacity of eels to adapt to changing environmental conditions around the world. Some scientists suggest that the cumulative impacts of global environmental change, including climate change, may lead to the collapse of eel and other of aquatic species, even in species that possess a high adaptive capacity (August and Hicks 2008; Capon et al. 2013; Death et al. 2016; Drouineau et al. 2018; Pacariz et al. 2014). Despite the limited research (mātauranga Māori and/or scientific studies) into the impacts of climate change on Aotearoa's tuna and reducing the vulnerability of tuna (Jellyman et al. 2009; 'Tuna-customary fisheries' 2012), there are indications within 
the Waipā catchment that climate change (in combination with other environmental stresses) will negatively affect Māori capacities to harvest tuna in the future.

The lack of attention to the health of tuna, in part, highlights the ways in which climate change and other environmental problems are often treated (by those employing Western knowledge) as distinct and entirely separate issues rather than holistic and interconnected issues (markers of the Anthropocene). Moreover, it demonstrates how Te Ao Pākehā (the Pākehā worldview) continues to shape what researchers, decision-makers, and environmental management practitioners consider to be worthy topics of study and what actions should be taken to conserve particular plants and animals. Tuna remains largely overlooked by those looking for evidence of the Anthropocene (as opposed to those interested in water quality) because tuna are not highly valued within Pākehā society (although tuna are commercially fished in small numbers). By and large, Pākehā recreational fishers seek to catch trout and salmon from Aotearoa's rivers and lakes (not eels); whereas, for Māori hapū and iwi, tuna remains a taonga. Tuna, through the settler-colonial gaze, are not viewed as 'iconic' evidence of climate change (instead Aotearoa-based researchers search for signs of rising sea levels, "sinking" islands, and Pacific climate refugees). For Māori, in contrast, the decline and loss of tuna (alongside many other native fauna) are important markers of the interconnected consequences of Anthropocene-settler-colonialism-climate change that requires action.

Our Ngāti Maniapoto research participants report the worsening health of tuna, despite ongoing river restoration projects along the Waipā River, but do not necessarily draw clear linkages between declining tuna numbers, poor-health, and climate change. In the upper catchment of the Waipā River, kaitiaki report that the tuna caught had liver fluke (a name for the group of parasitic trematodes Platyhelminthes) that can cause serious health problems in both tuna and other animals (including people) (Iwi Rep 2 2020; Iwi Rep 3 2020). Other kaitiaki reported working with scientists from the National Institute of Water and Atmospheric Research (NIWA - the New Zealand government research institute that focuses on climate, freshwater and ocean science) to try to understand why their tuna are sick. The scientists conducted autopsies on tuna and 
found parasitic worms (probably nematode) as well as liver fluke (Iwi Rep 4 2020; Iwi Rep 6 2020). Even tuna caught in the headwaters of the Waipā River, where the water quality is far better than downstream, have been found filled with invasive parasites. Tangata whenua are not sure what is causing the infestation of their tuna (which was a food source, a member of their extended family, and a taonga), though some suggest farming run-off might be responsible for parasitic infections (none mentioned climate change). One iwi representative asked:

what do you do to get rid of it is what I want to know in your scientific world. How do you drench an eel? What sort of chemical ... it would be an ideal to find out [what we could use] if we had one eel that did worms and give it a [chemical or] cider vinegar and if it does bring the worms out? (Iwi Rep 2 2020)

The causes of declining tuna health (both in terms of health status and numbers) as well as other aquatic biota in the Waipā River was uncertain (even amongst the freshwater scientists we interviewed), although some raised the issues of increased water allocation, intensification of dairy farming, and climate change. Instead, declining river health was discussed in terms of loss of vegetation and biodiversity, land-use changes, marginalisation of mātauranga Māori and iwi rangatiratanga (tribal authority), and polluting practices (sedimentation, agricultural run-off, effluent discharge) rather than global climate change. Yet, iwi representatives argued they were in dire need of information about climate change, and the topic was not widely discussed amongst government or co-governance bodies. Iwi representatives argued they wanted research and practical explanations of the ways in which they (and others) could protect and enhance tuna habitat in the context of changing environmental conditions. For iwi, being able to care for the tuna both now and in the future was an essential part of their intergenerational duties as kaitiaki (Iwi Rep 2 2020).

In previous chapters, we recount stories of tuna prized, caught, and lost. When once abundant, tuna swam in the peat lakes, flowing rivers and porous wetlands. The destruction of pā tuna, straightening of the river, pollution and presence of unwanted vegetation have led to reduced 
catches by Ngāti Maniapoto, and also speak to the complexities, multiple histories, and socio-cultural and political vitality of storied freshwater spaces. Tuna, like land, water, and other taonga are figuratively and literally connections between humans and more-than-human worlds that spiral through time and bind everything together through whakapapa (including mātauranga Māori, tikanga, and Māori as members of whānau, hapū and iwi). It is worthwhile for Indigenous and non-Indigenous scholars and freshwater water management practitioners to consider freshwater, and its functions, as more than sites upon which humans enact history or as physical locations in which history (and the sediment washing off cleared land) accumulates. Rather, historic and contemporary manifestations of colonial violence are deeply interwoven with ecological violence (including those linked to climate change).

Scientific indicators and measures are frequently used as the only worthy (accurate and objective) evidence of ecological destruction; at present, tuna are not worthy of much attention, but herein we suggest it should be. Yet, as our research (and the work of other Indigenous scholars) demonstrates, Indigenous experiences, stories, histories, and knowledge(s) provide a rich body of evidence about how colonial invasion, violence, violations, oppression of Indigenous and other sovereign peoples resulted in radical challenges to social and ecological systems, including the impacts of climate change. Scientific reports and academic studies documenting the commencement, speed, and pace of the Anthropocene and the impacts of climate change rarely include such "fleshy stories" (to borrow Métis scholar Zoe Todd's term) that Indigenous elders around the globe tell younger generations about how once (before colonisation, hydro-electric dams, introduced species, pollution, and commercial fisheries) there was an abundance of fish that swam in their waterways. Nor do they tell stories of the fish that were (are) caught, cooked, preserved and fed to family, friends, visitors and kin members. As Todd writes, the evidence used to record the Anthropocene precludes "the flash of a school of minnows in the clear prairie lakes I intimately knew as a child ... the succulent white fish my stepdad caught from us from the Red Deer River when I was growing up" (Davis and Todd 2017, p. 767). The consequences of loss and damage to fish, therefore, extend 
beyond the physical and metaphysical conditions. Such lessons (evidence of nuanced human and nonhuman relations and environmental changes), she explains, are often overlooked and are:

deeply erased from dominant (non-Indigenous) public discourse in ... [Canada] and I had not recognized the implicit ways fish were woven into my own life as more than food. This is the thing about colonization: it tries to erase the relationships and reciprocal duties we share across boundaries, across stories, across species, across space, and it inserts new logics, new principles, and new ideologies in their place. (Todd 2016)

In Aotearoa, similarly, such fleshy stories of the interconnected, intergenerational, and reciprocal relationships between living entities (waters, flora and fauna, supernatural beings and peoples) are continually marginalised within how freshwater is governed and managed. In the Waipā River, river restoration is primarily directed at improving water quality (specifically through sedimentation reduction) rather than addressing other climate and non-climate risks (including flood control and loss of biodiversity) (Local Government Rep 1 2018; Local Government Rep 2 2019; Local Government Rep 3 2017). As local one government official informed us:

Restoration practices, such as fencing and planting of riparian zones, are important tools to improve waterway health and play a significant part in [regional] council achieving [its] goals and vision. This is reflected by the catchment management funding incentive available, not just in the Waipa catchment, but across the region to encourage landowners to undertake measures on their properties to improve the ecological health of waterways. (Local Government Rep 3 2017)

Many tangata whenua critique this narrow framing of river restoration, which only seeks to draw linkages between water quality and ecosystem integrity, but not to the health of nonhuman beings nor the reciprocal (kinship-based) relations between people, plants, insects, animals and water. Healthy waters equal healthy biota and healthy people (Iwi Rep 5 2019; Iwi Rep 6 2020; Kaitiaki 1 2020; Kaitiaki 5 2020). 
In contrast, mātauranga Māori emphasises interconnectivity between all beings (living and non-living) across time, and encompasses all generations (ancestors, people living now, and those who will live in the future). Within this holistic ontology, restoration efforts are inseparable from current and future efforts to reduce the pollution of air, water, land, and actions to mitigate and adapt to the impacts of climate change. All are focused on the same goal: the protection and enhancement of the mauri of all beings, and these goals and duties of care are intergenerational. Such a view is steeped in Māori perspectives of time as a temporal spiral wherein the present (such as the current state of the environmental degradation within the Waipā River) is not seen as more important than the past or future: it is one of equals (Rameka 2016; Winter 2019). Despite the emergence of co-governance and co-management arrangements for the Waipā River, Western ontologies and epistemologies continue to dominate river restoration (and the freshwater management more generally) and frame the past/present/future as discreetly separate domains. Although there is formal recognition in legislation that past policies and actions contributed to current environmental degradation in the Waipā River, for Pākehā that past is behind them and they do not carry the past (including their ancestors and their histories) with them in the present and future times. The goal of river management, therefore, continues to focus on the present and immediate future needs and priorities of people alive together, while other framings of time (including the distant past and future) and different generations (of human and morethan-human actors) remain excluded from consideration.

\section{Conclusion}

With ontological underpinnings premised on communitarianism and holism, Ngāti Maniapoto articulations of IEJ emphasise the ways in which everything is bound together across the neverending temporal spiral that interweaves past/present/future/past as coexisting times. Just as an injustice against one member of one's kin group (a river) is an injustice to all (metaphysical and social realms), similarly an injustice against a 
tūpuna (an ancestor), a person living today, or one living in the future is an injustice for all generations. As the previous chapters on wetland drainage and water pollution attest too, IEJ, in the context of Ngāti Maniapoto relationships with their awa, involves the lassoing and braiding together of different dimensions of justice, wherein pluralism (in ontologies, laws, management approaches) is an essential pathway by which just (tika) interactions with water, land, biota, time, and generations can be (re)established. We argue, following on from McGregor (2014) and Winter (2018), the ontological clashes between Te Ao Pākehā and Te Ao Māori rest in part on the former's anthropocentrism and individualism and latter's holism and communitarianism. Western intellectual frameworks underpinning EJ is framed in terms of justice for human beings, specifically individual rights and entitlements, including people's rights to clean water, air, food, dignity, participatory parity, and recognition of their cultural differences. In contrast, Ngāti Maniapoto EJ is about justice for both human and more-than-human entities within their rohe, with threats to the existence of beings that live within their awa threatening the health and wellbeing of mana whenua (past/present/ future generations). Moreover, from a Te Ao Māori perspective, environmental justice lassos human and more-than-human entities together reciprocial relationships premised on kinship ties. In this way the Waipa River, a non-human actor with its own agency, mana, and mauri, also provides waters, habitat, and connections that are life-affirming for diverse entities, including providing the lifeblood for the Ngāti Maniapoto people. In the worldview of Ngāti Maniapoto, all beings within their landscapes and waterscapes possess reciprocal responsibilities to each other which stretch across generations spiralling backwards and forwards through time. EJ in the context of freshwater governance and management is much wider than the 'impacts' of freshwater degradation on people's health; it also extends to include duties that ensure the continuation of more-than-human entities and processes linked to the continuation of metaphysical realms and the current and future impacts of climate change on material and metaphysical worlds. Climate injustices, as we demonstrate in regard to the example of tuna (eels), can and are occurring for more-than-human beings not only when their habitats are degraded and destroyed through drainage, forest clearance, water pollution, and 
climate change, but also because of misrecognition of the mana (power and status) of tuna, its mauri, and the interconnection of tuna to the health and wellbeing of tangata whenua.

\section{References}

Aarestrup, K., Thorstad, E. B., Koed, A., Svendsen, J. C., Jepsen, N., Pedersen, M. I., \& Økland, F. (2010). Survival and Progression Rates of Large European Silver Eel Anguilla Anguilla in Late Freshwater and Early Marine Phases. Aquatic Biology, 9(3), 263-270.

Adler, A. A., Doole, G. J., Romera, A. J., \& Beukes, P. C. (2013). Cost-effective Mitigation of Greenhouse Gas Emissions from Different Dairy Systems in the Waikato Region of New Zealand. Journal of Environmental Management, 131, 33.

Alfred, T. (2008). Peace, Power, Righteousness: An Indigenous Manifesto (2nd ed.). New York: Oxford University Press Canada.

Alfred, T. (2015). Cultural Strength: Restoring the Place of Indigenous Knowledge in Practice and Policy. Australian Aboriginal Studies, 1, 3.

Arai, T. (2014). Do We Protect Freshwater Eels or Do We Drive Them to Extinction? SpringerPlus, 3(1), 534.

August, S. M., \& Hicks, B. J. (2008). Water Temperature and upstream migration of glass eels in New Zealand: implications of climate change. Environmental Biology of Fishes, 81(2), 195-205.

Baldwin, A. (2009). Carbon Nullius and Racial Rule: Race, Nature and the Cultural Politics of Forest Carbon in Canada. Antipode, 41(2), 231-255.

Ballantine, D. J., \& Davies-Colley, R. J. (2014). Water Quality Trends in New Zealand Rivers: 1989-2009. Environmental Monitoring and Assessment, 186(3), 1939-1950.

Barnett, J., Evans, L., Gross, C., Kiem, A., Kingsford, R., Palutikof, J., et al. (2015). From Barriers to Limits to Climate Change Adaptation: Path Dependency and the Speed of Change. Ecology and Society, 20(3).

Barnett, J., \& O’Neill, S. (2010). Maladaptation. Global Environmental Change, 20(2), 211-213.

Baum, A. (2019). Mni Wiconi (Water is Life): Knowledge, Power and Resistance at Standing Rock. Ideas from IDS: Graduate Papers from 2017/18, 9.

Bell, D. (2011). Global Climate Justice, Historic Emissions, and Excusable Ignorance. The Monist, 94(3), 391-411. 
Bell, D. (2013). Climate Change and Human Rights. WIREs Climate Change, 4(3), 159-170.

Brännlund, I., \& Axelsson, P. (2011). Reindeer Management During the Colonization of Sami lands: A Long-term Perspective of Vulnerability and Adaptation Strategies. Global Environmental Change, 21(3), 1095-1105.

Brownsey, P. (2019, December 12). Addressing Climate Change Through Investment in GlobalMarkets, Paul Brownsey, CIO Pathfinder Asset Management. Workshop Presentation presented at the The Waikato River Authority, Responding to Climate Change for the Waikato and Waipā rivers-implications for Te Ture Whaimana/Vision \& Strategy, Waikato-Tainui Endowed College, Ngaruawahia. Retrieved April 29, 2020, from https://waikatoriver. org.nz/climate-change-workshop/.

Callison, C. (2015). How Climate Change Comes to Matter: The Communal Life of Facts. Durham: Duke University Press.

Cameron, E. S. (2012). Securing Indigenous Politics: A Critique of the Vulnerability and Adaptation Approach to the Human Dimensions of Climate Change in the Canadian Arctic. Global Environmental Change, 22(1), 103-114.

Caney, S. (2008). Global Distributive Justice and the State. Political Studies, 56(3), 487-518.

Caney, S. (2009). Justice and the Distribution of Greenhouse Gas Emissions. Journal of Global Ethics, 5(2), 125-146.

Caney, S. (2014). Two Kinds of Climate Justice: Avoiding Harm and Sharing Burdens. Journal of Political Philosophy, 22(2), 125-149.

Capon, S. J., Chambers, L. E., Mac Nally, R., Naiman, R. J., Davies, P., Marshall, N., et al. (2013). Riparian Ecosystems in the 21st Century: Hotspots for Climate Change Adaptation? Ecosystems, 16(3), 359-381.

Carter, L. (2018). Indigenous Pacific Approaches to Climate Change: Aotearoal New Zealand. Cham: Palgrave Pivot.

Chapman, M. A. (1996). Human Impacts on the Waikato River System, New Zealand. GeoJournal, 40(1), 85-99.

Cook, M. (2016). Damming the 'Flood Evil' on the Brisbane River. History Australia, 13(4), 540-556.

Cook, M. (2018). "It Will Never Happen Again”: The Myth of Flood Immunity in Brisbane. Journal of Australian Studies, 42(3), 328-342.

Davis, H., \& Todd, Z. (2017). On the Importance of a Date, or Decolonizing the Anthropocene. ACME: An International E-Journal for Critical Geographies, 16(4), 1. 
Death, R., Bowie, S., \& O'Donnell, C. (2016). 3. Vulnerability of freshwater ecosystems due to climate change. Freshwater conservation under a changing climate, 14.

Dickie, B. (2019, December 12). The challenge of climate change adaptation and mitigation in the Waikato Region, Blair Dickie, Waikato Regional Authority. Workshop Presentation presented at the The Waikato River Authority, Responding to Climate Change for the Waikato and Waipā rivers-implications for Te Ture Whaimana/Vision \& Strategy, Waikato-Tainui Endowed College, Ngaruawahia. Retrieved June 8, 2020, from https://waikatoriver. org.nz/climate-change-workshop/.

Dotson, K. (2011). Tracking Epistemic Violence, Tracking Practices of Silencing. Hypatia, 26(2), 236-257.

Dotson, K. (2014). Conceptualizing Epistemic Oppression. Social Epistemology, 28(2), 115-138.

Dressler, W., McDermott, M., Smith, W., \& Pulhin, J. (2012). REDD Policy Impacts on Indigenous Property Rights Regimes on Palawan Island, The Philippines. Human Ecology, 40(5), 679-691.

Driver, E., Parsons, M., \& Fisher, K. (2018). Technically Political: The Postpolitics(?) of the New Zealand Emissions Trading Scheme. Geoforum, 97, 253-267.

Drouineau, H., Durif, C., Castonguay, M., Mateo, M., Rochard, E., Verreault, G., et al. (2018). Freshwater Eels: A Symbol of the Effects of Global Change. Fish and Fisheries, 19(5), 903-930.

Dudley, B. D., Burge, O., Plew, D. R., \& Zeldis, J. (2020). Effects of Agricultural and Urban Land Cover on New Zealand's Estuarine Water Quality. New Zealand Journal of Marine and Freshwater Research, 54, 1-21.

Durie, M. (1998). Te mana, te kāwanatanga: The Politics of Māori selfdetermination. Auckland: Oxford University Press.

Fox, C. A., Reo, N. J., Turner, D. A., Cook, J., Dituri, F., Fessell, B., et al. (2017). "The River Is Us; The River Is in Our Veins": Re-defining River Restoration in Three Indigenous Communities. Sustainability Science, 1, 1-13.

Gerrard, E. (2012). Towards a Carbon Constrained Future: Climate Change, Emissions Trading and Indigenous Peoples' Rights in Australia. In J. K. Weir (Ed.), Country, Native Title and Ecology (1st ed., pp. 135-174). Canberra: ANU Press.

Gilio-Whitaker, D. (2019). As Long as Grass Grows: The Indigenous Fight for Environmental Justice from Colonization to Standing Rock. Boston: Beacon Press. 
Harawira, H. (2007, December 11). Harawira, Hone: Climate Change (Emissions Trading and Renewable Preference) Bill-First Reading-New Zealand Parliament. Hansard (Parliamentary Debates). New Zealand Parliament. Retrieved June 10, 2020, from https://www.parliament.nz/en/ $\mathrm{pb} /$ hansard-debates/rhr/document/48HansS_20071212_00000875/ harawira-hone-climate-change-emissions-trading-and-renewable.

Hayward, B. (2008). 'Nowhere Far from the Sea': Political Challenges of Coastal Adaptation to Climate Change in New Zealand. Political Science, 60(1), 47-59.

Hayward, T., \& Iwaki, Y. (2016). Had We But World Enough, and Time: Integrating the Dimensions of Global Justice. Critical Review of International Social and Political Philosophy, 19(4), 383-399.

Hoegh-Guldberg, O., Jacob, D., Bindi, M., Brown, S., Camilloni, I., Diedhiou, A., et al. (2018). Impacts of $1.5^{\circ} \mathrm{C}$ Global Warming on Natural and Human Systems. In Global warming of $1.5^{\circ}$ C.: An IPCC Special Report (pp. 175-311). IPCC Secretariat. Retrieved May 1, 2020, from https://researchportal.helsinki.fi/en/publications/impacts-of-15c-global-warming-on-naturaland-human-systems.

Hopkins, D., Campbell-Hunt, C., Carter, L., Higham, J. E. S., \& Rosin, C. (2015). Climate Change and Aotearoa New Zealand: Climate Change and Aotearoa New Zealand. Wiley Interdisciplinary Reviews: Climate Change, 6(6), 559-583.

Howitt, R., Havnen, O., \& Veland, S. (2012). Natural and Unnatural Disasters: Responding with Respect for Indigenous Rights and Knowledges. Geographical Research, 50(1), 47-59.

Ivison, D. (2003). The Logic of Aboriginal Rights. Ethnicities, 3(3), 321-344. https://doi.org/10.1177/14687968030033003.

Ivison, D. (2014). Indigenous Peoples' Rights. In The Encyclopedia of Political Thought (pp. 1815-1817). American Cancer Society. Retrieved June 28, 2020, from https://doi.org/10.1002/9781118474396.wbept0503. Iwi Rep 2. (2020, February 13). Interview with Iwi Representative 2. Iwi Rep 3. (2020, February 13). Interview with iwi Representative 3. Iwi Rep 4. (2020, February 14). Interview with Iwi Representative 4. Iwi Rep 5. (2019, March 25). Interview with Interview Iwi Representative 5. Iwi Rep 6. (2020, February 14). Interview with Iwi Representative 6. Iwi Rep 9. (2019, October 9). Interview with Iwi Representative 9. Jellyman, D. J., Booker, D. J., \& Watene, E. (2009). Recruitment of Anguilla spp. glass eels in the Waikato River, New Zealand. Evidence of declining migrations? Journal of Fish Biology, 74(9), 2014-2033. 
Kaitiaki 1. (2020, February 4). Interview with Kaitiaki 1. Kaitiaki 5. (2020, February 5). Interview with Kaitiaki 5. Klein, R. J., Nicholls, R. J., Ragoonaden, S., Capobianco, M., Aston, J., \& Buckley, E. N. (2001). Technological Options for Adaptation to Climate Change in Coastal Zones. Journal of Coastal Research, 20, 531-543.

Klein, R. J. (2011). Adaptation to Climate Change. In I. Linkov \& T. S. Bridges (Eds.), Climate (pp. 157-168). Dordrecht: Springer Netherlands.

Ledgard, S. (2019, December 12). Addressing Biological Emissions: Mitigation and Co-benefits on Farms, Dr Stewrad Ledgard, Principal Scientist AgResearch. Workshop Presentation presented at the The Waikato River Authority, Responding to Climate Change for the Waikato and Waipā rivers-implications for Te Ture Whaimana/Vision \& Strategy, Waikato-Tainui Endowed College, Ngaruawahia. Retrieved April 29, 2020, from https://waikatoriver. org.nz/climate-change-workshop/.

LeQuesne, T. (2019). Petro-hegemony and the Matrix of Resistance: What Can Standing Rock's Water Protectors Teach Us About Organizing for Climate Justice in the United States? Environmental Sociology, 5(2), 188-206.

Li, T. M. (2010). Indigeneity, Capitalism, and the Management of Dispossession. Current Anthropology, 51(3), 385-414.

Linwood, R. (2019, December 12). Freshwater Policy and Climate Change: Synergy and Co-benefits, Rachelle Linwood, Manager Freshwater Policy, Ministry of Primary Industries. Workshop Presentation presented at the The Waikato River Authority, Responding to Climate Change for the Waikato and Waipā rivers-implications for Te Ture Whaimana/Vision \& Strategy, WaikatoTainui Endowed College, Ngaruawahia. Retrieved April 29, 2020, from https://waikatoriver.org.nz/climate-change-workshop/.

Local Government Rep 1. (2018, October 4). Interview with Local Government Representative 1.

Local Government Rep 2. (2019, March 25). Interview with Local Government Representative 2.

Local Government Rep 3. (2017, September 29). Interview with Local Government Representative 3.

Love, T., \& Tilley, E. (2013). Temporal Discourse and the News Media Representation of Indigenous-Non-Indigenous Relations: A Case Study from Aotearoa New Zealand. Media International Australia, 149(1), 174-188. https://doi.org/10.1177/1329878X1314900118.

Magnan, A. K., Schipper, E. I. F., Burkett, M., Bharwani, S., Burton, I., Eriksen, S., et al. (2016). Addressing the Risk of Maladaptation to Climate Change. Wiley Interdisciplinary Reviews: Climate Change, 7(5), 646-665. 
Manning, M., Lawrence, J., King, D. N., \& Chapman, R. (2015). Dealing with Changing Risks: A New Zealand Perspective on Climate Change Adaptation. Regional Environmental Change, 15(4), 581-594.

McGregor, D. (2014). Traditional Knowledge and Water Governance: The Ethic of Responsibility. AlterNative: An International Journal of Indigenous Peoples, 10(5), 493-507.

Mckay, B., \& Walmsley, A. (1969). Maori Time: Notions of Space, Time and Building Form in the South Pacific. Idea Journal, 20, 85-95.

McMillen, H., Ticktin, T., \& Springer, H. K. (2017). The Future Is Behind Us: Traditional Ecological Knowledge and Resilience Over Time on Hawai' $\mathrm{i}$ Island. Regional Environmental Change, 17(2), 579-592.

Mills, C. W. (2015). Race and Global Justice. In Domination and Global Political Justice (pp. 193-217). New York: Routledge.

Myers, C. A., Slack, T., \& Singelmann, J. (2008). Social Vulnerability and Migration in the Wake of Disaster: The Case of Hurricanes Katrina and Rita. Population and Environment, 29(6), 271-291.

National Business Review. (2018, July 11). Iwi Leaders Complain Weak ETS Destroying Maori Asset Value. NBR. Retrieved June 10, 2020, from https:// www.nbr.co.nz/article/iwi-leaders-complain-weak-ets-destroying-maoriasset-values-bd-130795.

New Zealand, Ministry for the Environment, New Zealand, \& Stats NZ. (2020).

Our freshwater 2020. Retrieved April 28, 2020, from https:/www.mfe.govt. $\mathrm{nz} /$ sites/default/files/media/Environmental\%20reporting/our-freshwater-2020.pdf.

NGO Rep 1. (2017, September 28). NGO Representative 1.

Nightingale, A. J., Eriksen, S., Taylor, M., Forsyth, T., Pelling, M., Newsham, A., et al. (2019). Beyond Technical Fixes: Climate Solutions and the Great Derangement. Climate and Development, 12(4), 343-352.

Nursey-Bray, M. (2016). Cultural Indicators, Country and Culture: The Arabana, Change and Water. The Rangeland Journal, 37(6), 555-569.

Nursey-Bray, M., Palmer, R., Smith, T. F., \& Rist, P. (2019). Old Ways for New

Days: Australian Indigenous Peoples and Climate Change. Local Environment, 1, 1-14.

Pacariz, S., Westerberg, H., \& Björk, G. (2014). Climate Change and Passive Transport of European Eel Larvae. Ecology of Freshwater Fish, 23(1), 86-94. Page, E. A. (2007a). Intergenerational Justice of What: Welfare, Resources or Capabilities? Environmental Politics, 16(3), 453-469.

Page, E. A. (2007b). Climate Change, Justice and Future Generations. Cheltenham; Northampton, MA: Edward Elgar Publishing. 
Parfit, D. (2011). On What Matters. Oxford: Oxford University Press.

Parsons, M., \& Nalau, J. (2016). Historical Analogies as Tools in Understanding Transformation. Global Environmental Change, 38, 82-96.

Parsons, M., Nalau, J., Fisher, K., \& Brown, C. (2019). Disrupting Path Dependency: Making Room for Indigenous Knowledge in River Management. Global Environmental Change, 56, 95-113.

Patterson, J. (1998). Respecting Nature: A Maori Perspective. Worldviews: Global Religions, Culture, and Ecology, 2(1), 69-78.

Pearce, P. (2019, December 12). Climate Change-What Does It Mean for Waikato? Petra Pearce, Manager, Climate, Atmosphere and Hazards, NIWA. Workshop Presentation presented at the The Waikato River Authority, Responding to Climate Change for the Waikato and Waipā rivers-implications for Te Ture Whaimana/Vision \& Strategy, Waikato-Tainui Endowed College, Ngaruawahia. Retrieved April 29, 2020, from https://waikatoriver. org.nz/climate-change-workshop/.

Pelling, M., Manuel-Navarrete, D., \& Redclift, M. (2012). Climate Change and the Crisis of Capitalism: A Chance to Reclaim, Self, Society and Nature. Routledge. Retrieved April 27, 2017, from https://books.google.co.nz/books ?hl=en\&lr=\&id=Wy7zD66p9ngC\&oi=fnd\&pg=PP2\&dq=Pelling+Navarret te\&ots=R2gdQaucD7\&sig=899ymbdnBRY7apxRN6NmLE5yLmE.

Povinelli, E. A. (2016). Geontologies: A Requiem to Late Liberalism. Durham: Duke University Press.

Povinelli, E. A., Coleman, M., \& Yusoff, K. (2017). An Interview with Elizabeth Povinelli: Geontopower, Biopolitics and the Anthropocene. Theory, Culture \& Society, 34(2-3), 169-185.

Rameka, L. (2016). Kia whakatōmuri te haere whakamua: 'I Walk Backwards into the Future with My Eyes Fixed on My Past': Contemporary Issues in Early Childhood.

Rangel-Buitrago, N., Williams, A., \& Anfuso, G. (2017). Hard Protection Structures as a Principal Coastal Erosion Management Strategy Along the Caribbean Coast of Colombia. A Chronicle of Pitfalls. Ocean \& Coastal Management, 156(58-75), 1.

Reisinger, A., Kitching, R. L., Chiew, F., Hughes, L., Newton, P. C., Schuster, S. S., et al. (2014). Australasia. In V. R. Barros, C. B. Field, M. D. Dokken, P. R. Mastrandrea, \& L. L. White (Eds.), Climate Change 2014: Impacts, Adaptation, and Vulnerability. Part B: Regional Aspects. Contribution of Working Group II to the Fifth Assessment Report of the Intergovernmental Panel on Climate Change (pp. 1371-1438). Cambridge and New York: Cambridge University Press. Retrieved April 21, 2017 from https://www.researchonline. mq.edu.au/vital/access/manager/Repository/mq:60146. 
Reisinger, A., Wratt, D., Allan, S., \& Larsen, H. (2011). The Role of Local Government in Adapting to Climate Change: Lessons from New Zealand. In J. D. Ford \& L. Berrang-Ford (Eds.), Climate Change Adaptation in Developed Nations: From Theory to Practice (pp. 303-319). Dordrecht: Springer Netherlands.

Rohland, E. (2018). Adapting to Hurricanes. A Historical Perspective on New Orleans from Its Foundation to Hurricane Katrina, 1718-2005. Wiley Interdisciplinary Reviews: Climate Change, 9(1), e488.

Roy, J., Tschakert, P., Waisman, H., Halim, S. A., Antwi-Agyei, P., Dasgupta, P., et al. (2019). Sustainable Development, Poverty Eradication and Reducing Inequalities. In V. Masson-Delmotte, P. Zhai, H. O. Pörtner, D. Roberts, J. Skea, P. R. Shukla, et al. (Eds.), Global Warming of $1.5^{\circ} \mathrm{C}$. An IPCC Special Report on the impacts of global warming of $1.5^{\circ} \mathrm{C}$ above pre-industrial levels and related global greenhouse gas emission pathways, in the context of strengthening the global response to the threat of climate change, sustainable development, and efforts to eradicate poverty (pp. 445-538). Intergovernmental Panel on Climate Change. Retrieved June 9, 2020, from https://www.ipcc.ch/site/assets/ uploads/sites/2/2019/05/SR15_Chapter5_Low_Res.pdf.

Rumbach, A., \& Foley, D. (2014). Indigenous Institutions and Their Role in Disaster Risk Reduction and Resilience: Evidence from the 2009 Tsunami in American Samoa. Ecology and Society, 19(1), 1-9.

Salmond, D. A. (2020). Afterword: 'I Am the River, and the River Is Me'. The Contemporary Pacific, 32(1), 164-171.

Schlosberg, D. (2012). Climate Justice and Capabilities: A Framework for Adaptation Policy. Ethics \& International Affairs, 26(4), 445-461.

Schlosberg, D., \& Collins, L. B. (2014). From Environmental to Climate Justice: Climate Change and the Discourse of Environmental Justice. Wiley Interdisciplinary Reviews: Climate Change, 5(3), 359-374.

Shue, H. (2014). Climate Justice: Vulnerability and Protection. Oxford: Oxford University Press.

Stern, N., Stern, N. H., \& Treasury, G. B. (2007). The Economics of Climate Change: The Stern Review. Cambridge: Cambridge University Press.

Stewart-Harawira, M. (2005). Cultural Studies, Indigenous Knowledge and Pedagogies of Hope. Policy Futures in Education, 3(2), 153-163.

Stewart-Harawira, M. (2018). Indigenous Resilience and Pedagogies of Resistance: Responding to the Crisis of Our Age (May 27, 2018). Available at SSRN: https://ssrn. com/abstract $=3185625$ or https://doi.org/10.2139/ssrn.3185625

Todd, Z. (2016). 'You Never Go Hungry' : Fish Pluralities, Human-fish Relationships, Indigenous Legal Orders and Colonialism in Paulatuuq, Canada 
(Thesis). University of Aberdeen, Aberdeen. Retrieved June 8, 2019, from http://digitool.abdn.ac.uk:80/webclient/DeliveryManager?pid=231448.

Tuna-customary fisheries. (2012, January 26). NIWA. Retrieved August 13, 2017, from https://www.niwa.co.nz/te-k\%C5\%ABwaha/tuna-informationresource/pressures-on-new-zealand-populations/customary-tuna-fisheries.

Unknown Author. (2009, November 16). National's ETS to Include Special Treatment for Maori. News Hub. Retrieved June 10, 2020, from https:// www.newshub.co.nz/general/nationals-ets-to-include-special-treatmentfor-maori-2009111617.

Unknown Author. (2019, November 19). Waikato River Authority Workshop to Tackle Climate Change | Stuff.co.nz. Waikato Times. Hamilton. Retrieved April 28, 2020, from https://www.stuff.co.nz/waikato-times/ news/117357753/waikato-river-authority-workshop-to-tackle-c limate-change.

Veland, S., Howitt, R., Dominey-Howes, D., Thomalla, F., \& Houston, D. (2013). Procedural Vulnerability: Understanding Environmental Change in a Remote Indigenous Community. Global Environmental Change, 23(1), 314-326.

Vinyeta, K., Whyte, K., \& Lynn, K. (2016). Climate Change Through an Intersectional Lens: Gendered Vulnerability and Resilience in Indigenous Communities in the United States (SSRN Scholarly Paper No. ID 2770089). Rochester, NY: Social Science Research Network. Retrieved February 8, 2018, from https://papers.ssrn.com/abstract=2770089.

Waikato River Authority. (2019). Responding to Climate Change for the Waikato and Waipā rivers_implications for Te Ture Whaimana/Vision \& Strategy, Hui summary and notes, Waikato-Tainui Endowed College, Ngaruawahia, 12 December 2019. Unpublished. Retrieved April 29, 2020, from https://waikatoriver.org.nz/climate-change-workshop/.

Watene, K. (2016). Valuing Nature: Māori Philosophy and the Capability Approach. Oxford Development Studies, 44(3), 287-296.

Watson, I. (2015). Aboriginal Peoples, Colonialism and International Law. Abingdon, Oxon: Routledge.

West, D. W. (2007). Responses of Wild Freshwater Fish to Anthropogenic Stressors in the Waikato River of New Zealand (Thesis). The University of Waikato. Retrieved August 15, 2019, from https://researchcommons.waikato.ac.nz/ handle/10289/2601.

Whyte, K. (2020). Too Late for Indigenous Climate Justice: Ecological and Relational Tipping Points. WIREs Climate Change, 11(1), e603. https://doi. org/10.1002/wcc.603. 
Whyte, K. L., Talley, J., \& Gibson, J. (2019). Indigenous Mobility Traditions, Colonialism, and the Anthropocene. Mobilities, 14(3), 319-335. https://doi. org/10.1080/17450101.2019.1611015.

Whyte, K. (2017). The Dakota Access Pipeline, Environmental Injustice, and U.S. Colonialism. Red Ink: An International Journal of Indigenous Literature, Arts, \& Humanities, (19.1). Retrieved June 8, 2019, from https://ssrn.com/ abstract $=2925513$.

Winter, C. J. (2018). The Paralysis of Intergenerational Justice: Decolonising Entangled Futures. Retrieved January 11, 2020, from https://ses.library.usyd. edu.au/handle/2123/18009.

Winter, C. J. (2019). Does Time Colonise Intergenerational Environmental Justice Theory? Environmental Politics, 1, 1-19.

Yenneti, K., Day, R., \& Golubchikov, O. (2016). Spatial Justice and the Land Politics of Renewables: Dispossessing Vulnerable Communities Through Solar Energy Mega-projects. Geoforum, 76, 90-99.

Zahara, A. (2017, March 14). Difference in the Anthropocene: Indigenous Environmentalism in the Face of Settler Colonialism. Discard Studies. Retrieved June 10, 2020, from https://discardstudies.com/2017/03/14/ difference-in-the-anthropocene-indigenous-environmentalism-in-the-faceof-settler-colonialism/.

Open Access This chapter is licensed under the terms of the Creative Commons Attribution 4.0 International License (http://creativecommons.org/licenses/ by/4.0/), which permits use, sharing, adaptation, distribution and reproduction in any medium or format, as long as you give appropriate credit to the original author(s) and the source, provide a link to the Creative Commons licence and indicate if changes were made.

The images or other third party material in this chapter are included in the chapter's Creative Commons licence, unless indicated otherwise in a credit line to the material. If material is not included in the chapter's Creative Commons licence and your intended use is not permitted by statutory regulation or exceeds the permitted use, you will need to obtain permission directly from the copyright holder.

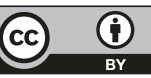

